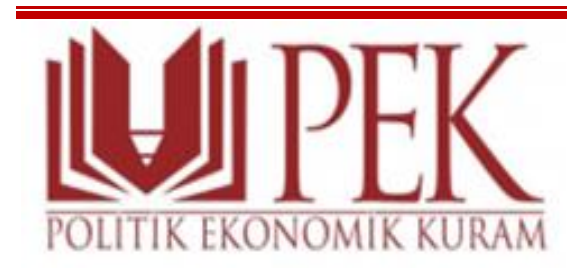

2021, Cilt 5, Sayı 1, 19-33

\section{POLITIKK EKONOMIK KURAM}

E-ISSN: 2587-2567

https://dergipark.org.tr/tr/pub/pek

Doi: $10.30586 /$ pek.902428

Makale Geliş Tarihi: 24.03.2021

Makale Kabul Tarihi: 22.05.2021

Araştırma Makalesi

\title{
İktisadi Büyüme Teorilerini Yeniden Düşünmek: Avustralya ve Bangladeş Örneği
}

\section{Rethinking Economic Growth Theories: The Case of Australia and Bangladesh}

\author{
Baybarshan Ali KAZANCI ${ }^{1}$, Taner TÜMER ${ }^{2}$, Hacer Özlem ÜLKER ${ }^{3}$, İbrahim AYTEKİN ${ }^{4}$ \\ Öz
}

Teknolojik gelişmeler ve dönüşümler ile ortaya çıkan Sanayi Devrimi, 18. yüzyılda ülkelerin üretim kapasitelerini artırmıştır. Üretim kapasitelerinde görülen bu artışlar iktisadi büyüme olarak ifade edilmektedir. Dolayısıyla günümüzde iktisadi büyüme, ülkelerin temel iktisadi hedeflerinden biri haline gelmiştir. Bu çalışmada 1990 ile 2019 yılları arasında oldukça başarılı bir büyüme performansı sergileyen Bangladeş ve Avustralya ele alınmıştır. Bu ülkelerin son otuz yıldaki iktisadi büyüme performansları Dünya büyüme rakamlarının üzerinde seyretmiştir. Ayrıca bu ülkeler bu süreçte küresel ve yerel çaptaki konjonktürel dalgalanmalardan çok az etkilenmiştir. Dolayısıyla bu çalışmada bu ülkelerin 1990-2019 yılları arasındaki iktisadi büyüme rakamları ile Dünya'nın büyüme rakamları istatistiki açıdan karşılaştırılarak değerlendirilmiştir. Bu bağlamda çalışmada öncelikle Avustralya ve Bangladeş'in genel ekonomik karakteristiğine vurgu yapan çalışmalarla ilgili bir literatür tarama çalışması yapılmıştır. Daha sonra büyüme teorileri kısaca vurgulanmış ve sonuç bölümünde ekonomik büyüme teorileri üzerine yorumlar kaleme alınmıştır.

Anahtar Kelimeler: Avustralya, Bangladeş, İktisat Teorileri, İktisadi Büyüme

Jel Kodları: O40, 047, O50, 057

\begin{abstract}
Industrial Revolution that emerged with Technological developments and transformations has increase the production capacities of countries in the eighteenth century. Hence, increase of production goods and services are expresse as the economic growth. economic growth has become one of the main economic targets of countries nowadays. In this study, Bangladesh and Australia has discussed which show a very successful growth performance between 1990 and 2019. The economic growth performances of these countries has been above the world growth figures in the last thirty years. In addition, these countries has little affected by the global and local conjuncture fluctuations in this process. Therefore, in this study, two countries' has evaluated the economic growth figures of and the growth figures the world as statistically between the years of 1990 and 2019. In this context, Australia and Bangladesh on studies that emphasize the general economic characteristics of has conducted a literature review study. Then, growth theories are briefly emphasized, and in the conclusion section, on economic growth theories has wrote comments.
\end{abstract}

Keywords: Australia, Bangladesh, Economics Theories, Economic Growth

Jel Codes: O40, 047, O50, 057

\footnotetext{
${ }^{1}$ Öğr. Gör. Kırıkkale Üniversitesi Fatma Şenses SBMYO, Yönetim ve Organizasyon Bölümü, kazanci@kku.edu.tr, ORCID ID: 0000-0002-3407-3692

${ }^{2}$ Kırıkkale Üniversitesi SBE İktisat Anabilim Dalı, Doktora Öğrencisi, tanertumertt@gmail.com, ORCID ID: 00000003-3138-592X

${ }^{3}$ Kırıkkale Üniversitesi SBE İktisat Anabilim Dalı, Doktora Öğrencisi, hozlem@ outlook.com, ORCID ID: 0000-00034970-4319

${ }^{4}$ Dr. İktisat Anabilim Dalı, ibrahimaytekin63@gmail.com, ORCID ID: 0000-0002-3574-1007
} 
Kazanc1, B. A.; Tümer, T.; Ülker, H. Ö. \& Aytekin, İ. (2021), “İktisadi Büyüme Teorilerini Yeniden Düşünmek: Avustralya ve Bangladeş Örneği”, Politik Ekonomik Kuram, 5 (1), 19-33.

\section{Giriş}

Ekonomik büyüme teorileri, Klasik ekolün öncüsü Adam Smith'ten istikamet alarak Neo-Klasik içsel büyüme teorilerine kadar gelen süreç içerisinde sürekli gelişme göstermiştir. İlgili literatürler genel çerçevede incelendiğinde, ekonomik büyümenin ana belirleyicileri olan diş ticaret, tasarruflar, yatırımlar, üretim çeşitliliği, fiziksel ve beşerî sermaye, teknoloji, nüfus gibi birçok farklı değişkene akademisyenler tarafından atıf yapıldığı görülmektedir. Bununla birlikte her biri döneminin hâkim paradigması haline gelmiş olan bu teoriler ekseninde, makro iktisadi yapıları benzer nitelikte olan ekonomiler için genel geçer bir büyüme teorisinin varlı̆̆g da sorgulanan bir olgu olarak karşımıza çıkmaktadır. Bu bağlamda iktisadi yapıları tamamen farklı iki ülkenin ekonomik büyüme performanslarının benzerliği nasıl açılanacak sorusu, büyüme teorilerinin her ülkede aynı etkiye sahip olup olmadığını akıllara getirmektedir.

Salt bir ekonomik büyümeden ziyade, söz konusu sürecin istikrarlı bir şekilde sürdürülmesi de önem arz etmektedir. Ne var ki dünya ekonomileri incelendiğinde genel anlamda büyüme rakamlarında oynaklık olduğu görülmektedir. Bilhassa 1980'lerde ticari ve finansal dışa açılmanın hızlanması ile ülkeler, küresel büyümenin nimetlerinden daha fazla yararlanmakla birlikte, olası bir krizde de ülkelerarası geçişkenliğin söz konusu dışa açılık nedeniyle daha yüksek boyutlarda olduğu dünya ekonomisinde tecrübe edilmiştir. Bu sebepler, küresel piyasalara ne kadar entegre olmuşsa o derece krizlerden ve ekonomik genişlemeden etkilendiğini göstermektedir.

Krizlerin yayılma hızı ve derecesi küresel ekonomik büyüme rakamlarına etki ederek uzun dönemde istikrarsız bir görünüm ortaya koyduğunda karar alıcılar, ekonomide yaşanan dalgalanmayı azaltarak istikrarın tesis edilmesini mi, yoksa oynaklığın göz ardı edilerek ne pahasına olursa olsun büyümenin mi ana hedef olarak belirlenmesi gerektiği konusunda kararsız kalabilmektedir. Söz konusu negatif ilişkinin altında yatan temel sebep ise, büyüme rakamlarında yaşanan oynaklığın, yaratacağı belirsizlik ortamı nedeniyle yatırım ve tüketim harcamalarında meydana getireceği azalma ile açıklanmaktadır. Bu durumlardan dolayı bulanık ekonomik görünüm doğrudan yabancı yatırımlara, finansal piyasalardaki istikrarsızlıklara, iç talebin ve arzın efektifliğini bozmada olumsuz yönde tesirde bulunabileceği zihinlerde daima taze durmaktadır.

Bu noktalardan hareketle, son otuz yıllık dönemde dünya ekonomisinde büyüme ve konjonktürel dalgalanma bağlamında dışa açık ülkeler incelendiğinde Avustralya, Bangladeş, Guatemala ve Lao'nun dünya ortalamasına nispeten istikrarlı seyri göze çarpmaktadır. Yaşanan bölgesel ve küresel ekonomik krizlere karşın bu ülkelerin hem daha az oynaklığa hem de daha yüksek büyüme rakamlarına sahip olduğu görülmektedir. Bu tespit, oynaklık-büyüme arasındaki negatif ilişkiyi teyit eder niteliktedir. Cevaplanması gereken diğer soru ise, çalışmanın devamında tanıtılacağı gibi, birbirinden tamamen farklı iktisadi yapılara sahip olan bu ülkelerin nasıl olup da dünyanın geri kalanından daha başarılı bir görünüm sergilediği olmuştur. Yukarıda sayılan dört ülkeden Guatemala ve Lao'nun küçük ekonomilere sahip olması nedeniyle diğer iki ülkeden Avustralya ve Bangladeş çalışmaya dahil edilmiştir.

Bu çalışmada, Avustralya ve Bangladeş ekonomilerinin 1990 ile 2019 yılları arasında dünyadaki diğer ülkelerden pozitif olarak ayrışarak göstermiş oldukları istikrarlı ekonomik büyümenin makro düzeydeki genel bir analizi yapılmıştır. Analizde; ortalama büyüme, standart sapma, varyans, korelasyon ilişkisi ve zaman yolu grafiği yöntemleri kullanılmıştır. Bu bağlamda Dünya, Bangladeş ve Avustralya'nın iktisadi büyüme veriler Dünya Bankasının veri tabanından temin edilmiştir. Çalışmanın amacı, bu iki ülkenin yaşamış olduğu tecrübeler ışığında her birinin farklı dinamiklere vurgu yapması sebebiyle ekonomik büyüme teorilerinin yeniden gözden geçirilmesinin gerekliliğine vurgu yapmaktır. Dolayısıyla; ilk bölümde, iki ülkenin büyüme süreçlerinin gerek bireysel, gerekse karşılaştırmalı olarak incelendiği literatür çalışmalarına yer 
verilmiştir. İkinci bölümde büyüme teorilerine kısaca değinilmiştir. Üçüncü bölümde, Avustralya ve Bangladeş ekonomilerinin genel makro iktisadi yapıları üzerinde durulmuştur. Son bölümde ise bu iki ülkenin iktisadi büyüme rakamları ile Dünya büyüme rakamları arasındaki ilişkiler grafiksel ve istatistiki olarak analiz edilmiştir.

\section{Literatür Taraması}

Ekonomik büyüme kapsamında literatürde çok sayıda çalışma olmasına rağmen yalnızca bu iki ülkenin birlikte ele alındığı çalışma bulunmamaktadır. Avustralya ve Bangladeş'in genel ekonomik karakteristiklerine vurgu yapan makaleler incelendiğinde gelişmiş ülkeler sınıfinda yer alan Avustralya dünyanın önde gelen kömür ve demir cevheri madenlerine sahip olması, turizm sektöründe elde edilen gelir kaynakları öne çıkmaktadır. Ayrıca Çin ile yakın ticari ilişkiler ülkenin ekonomik büyüme sürecinin önemli bir bileşeni haline gelmektedir. Gelişmekte olan ülkeler grubunda yer alan Bangladeş ise, beşeri sermaye açısından Avustralya ile kıyaslanamayacak kadar geridedir. Hazır giyim sektörüne yoğunlaşan ve bu sektörde önemli bir ihracat kalemine sahip olan bu ülke özelinde yapılan çalışmalar genellikle doğrudan yabancı yatırımlar, dış ticaret ve eğitim gibi alanlara odaklanıldığını göstermektedir. Bu bağlamda Avustralya ve Bangladeş için yapılan literatür tarama çalışmaları ve bu çalışmalarda ulaşılan sonuçlar Tablo 1'de detaylı olarak verilmiştir.

Tablo 1. Literatür Tarama Tablosu

\begin{tabular}{|c|c|c|c|}
\hline $\begin{array}{l}\text { Yazar(lar) } \\
\text { (Yayın Yılı) }\end{array}$ & $\begin{array}{c}\text { Ülke(ler) } \\
\text { (Analiz } \\
\text { Dönemi) }\end{array}$ & Yöntem & Bulgu ve Sonuçlar \\
\hline $\begin{array}{c}\text { Hossain } \\
\& \\
\text { Hossain } \\
(2012)\end{array}$ & $\begin{array}{l}\text { Bangladeş, } \\
\text { Hindistan } \\
\text { ve } \\
\text { Pakistan } \\
(1972-2008)\end{array}$ & $\begin{array}{c}\text { Eşbütünleşme } \\
\text { ve } \\
\text { Nedensellik } \\
\text { Testi }\end{array}$ & $\begin{array}{l}\text { Bangladeş ve Hindistan için kısa ve } \\
\text { uzun dönemde eşbütünleşme ilişkisi } \\
\text { tespit edilemezken, Pakistan'da kısa } \\
\text { ve uzun dönemli ilişkinin olduğu } \\
\text { görülmüştür. Nedensellik testinde ise } \\
\text { Bangladeş’te GDP ile DYY arasında } \\
\text { nedensellik ilişkisi bulunmaz iken, } \\
\text { Hindistan ve Pakistan'da DYY } \\
\text { GDP'nin nedeni olduğu anlaş1lmıştır }\end{array}$ \\
\hline $\begin{array}{c}\text { Banerjee } \\
(2012)\end{array}$ & $\begin{array}{c}\text { Avustralya } \\
(1870-2008)\end{array}$ & $\begin{array}{l}\text { Eşbütünleşme } \\
\text { Analizi }\end{array}$ & $\begin{array}{l}\text { Çalışmada nüfus artışı büyüme } \\
\text { üzerinde olumsuz bir etkiye sahipken, } \\
\text { yenilikçi faaliyetin verimlilik artışı } \\
\text { üzerinde olumlu bir etkisi olmuştur. } \\
\text { Tahminler Schumpeterci büyüme } \\
\text { hipotezini güçlü bir şekilde } \\
\text { desteklemektedir; bu hipotez, } \\
\text { üretkenlik artışının ekonomideki } \\
\text { araştırma yoğunluğu seviyesinden } \\
\text { kaynaklandığını öngörülmektedir. }\end{array}$ \\
\hline $\begin{array}{l}\text { Khan } \\
\& \\
\text { Bashar } \\
(2015)\end{array}$ & $\begin{array}{c}\text { Avustralya } \\
\text { Yeni Zelanda } \\
(1980-2012)\end{array}$ & $\begin{array}{c}\text { Eşbütünleşme } \\
\text { ve } \\
\text { Nedensellik } \\
\text { Testi }\end{array}$ & $\begin{array}{l}\text { Kisa ve uzun dönemde eşbütünleşme } \\
\text { ilişkisi bulunuştur. Avustralya'da } \\
\text { sosyal harcamalardan ekonomik } \\
\text { büyümeye doğru, Yeni Zelanda'da } \\
\text { ise eğitim harcamalarından }\end{array}$ \\
\hline
\end{tabular}


Kazanc1, B. A.; Tümer, T.; Ülker, H. Ö. \& Aytekin, İ. (2021), “İktisadi Büyüme Teorilerini Yeniden Düşünmek: Avustralya ve Bangladeş Örneği”, Politik Ekonomik Kuram, 5 (1), 19-33.

\begin{tabular}{|c|c|c|c|}
\hline & & & $\begin{array}{l}\text { büyümeye doğru tek yönlü } \\
\text { nedensellik ilișkisi bulunmuștur. }\end{array}$ \\
\hline $\begin{array}{l}\text { Hussain } \\
\quad \& \\
\text { Hague } \\
(2016)\end{array}$ & $\begin{array}{l}\text { Bangladeş } \\
(1973-2014)\end{array}$ & $\begin{array}{l}\text { VAR } \\
\text { Analizi }\end{array}$ & $\begin{array}{l}\text { Bangladeş'te doğrudan yabanc1 } \\
\text { yatırımlar ve diş ticaretin, kişi başına } \\
\text { düşen gelir büyümesi ile uzun dönem } \\
\text { ilişki içerisinde olduğu tespit } \\
\text { edilmiştir. }\end{array}$ \\
\hline $\begin{array}{c}\text { Hanif } \\
\& \\
\text { Arshed }(2016)\end{array}$ & $\begin{array}{c}\text { SAARC } \\
\text { Ülkeleri; } \\
(1960-2013)\end{array}$ & $\begin{array}{r}\text { FMOLS } \\
\text { Analizi }\end{array}$ & $\begin{array}{l}\text { Sonuçlarına göre, yüksek öğrenime } \\
\text { kaydolma sayılarının büyüme } \\
\text { üzerinde daha güçlü pozitif etkiye } \\
\text { sahip olduğu sonucuna ulaşılmıştır. }\end{array}$ \\
\hline $\begin{array}{l}\text { Shafiullah } \\
\text { vd., } \\
(2016)\end{array}$ & $\begin{array}{c}\text { Avustralya } \\
(-)\end{array}$ & $\begin{array}{c}\text { Genel } \\
\text { Değerlendirme }\end{array}$ & $\begin{array}{l}\text { Avustralya'da akaryakıt ve } \\
\text { madencilik sektöründeki ihracatın } \\
\text { ekonomik büyüme üzerinde önemli } \\
\text { etkiye sahip olduğu sonucuna } \\
\text { ulașılmıștır. }\end{array}$ \\
\hline $\begin{array}{l}\text { Paramati } \\
\text { vd., } \\
(2017)\end{array}$ & $\begin{array}{l}26 \text { Gelişmiş ve } \\
18 \text { Gelişmekte } \\
\text { Olan Ülke } \\
(1995-2012)\end{array}$ & $\begin{array}{l}\text { Panel Veri } \\
\text { Analizi }\end{array}$ & $\begin{array}{l}\text { Hem gelişmiş hem de gelişmekte olan } \\
\text { ülkeler için turizmin ekonomik } \\
\text { büyüme üzerinde önemli etkilere } \\
\text { sahip olduğu yönünde ve turizme } \\
\text { dayalı büyüme hipotezini destekler } \\
\text { nitelikte bulgular elde etmiştir }\end{array}$ \\
\hline $\begin{array}{l}\text { Cashin } \\
\text { vd., } \\
(2017)\end{array}$ & $\begin{array}{l}26 \text { Ülke/Bölge } \\
\text { (1981-2013) }\end{array}$ & $\begin{array}{l}\text { VAR } \\
\text { Analizi }\end{array}$ & $\begin{array}{l}\text { Çin'de yaşanan \%1'lik negatif } \\
\text { GSYİH şokunun, küresel düzeyde } \\
\text { büyümeyi \%0,23 puan azaltmakla } \\
\text { birlikte, Avustralya bu şoktan - } \% 0,1 \\
\text { civarında etkilenmektedir. }\end{array}$ \\
\hline $\begin{array}{l}\text { Islam } \\
\& \\
\text { Muneer } \\
\text { (2018) }\end{array}$ & $\begin{array}{l}\text { Bangladeş } \\
\text { ve } \\
\text { Pakistan } \\
(1998-2017)\end{array}$ & $\begin{array}{c}\text { OLS } \\
\text { Yöntemi }\end{array}$ & $\begin{array}{l}\text { Hem kamu eğitim harcamaları hem } \\
\text { de toplam sağlık harcamaları her iki } \\
\text { ülkede de kişi başına düşen gayrisafi } \\
\text { yurtiçi hasıla ile istatistiki açıdan } \\
\text { anlamlıdır. Fakat bu ilişki } \\
\text { Bangladeş'te pozitif iken Pakistan'da } \\
\text { kamu eğitim harcamaları pozitif, } \\
\text { toplam sağlık harcamaları negatif bir } \\
\text { etkiye sahiptir. }\end{array}$ \\
\hline $\begin{array}{l}\text { Groenewold } \\
\quad(2018\end{array}$ & $\begin{array}{l}\text { Avustralya } \\
\text { ve } \\
\text { Çin } \\
(-)\end{array}$ & $\begin{array}{l}\text { Regresyon } \\
\text { ve } \\
\text { VAR Analizi }\end{array}$ & $\begin{array}{l}\text { Çin ekonomisinde yaşanan } \% 3 \text { 'lük } \\
\text { bir yavaşlama Avustralya'nın iktisadi } \\
\text { büyümesinde kısa dönemde } \% 0,21 \text {, } \\
\text { uzun dönemde ise } \% 0,43 \text { oranında bir } \\
\text { daralmaya yol açtığ } 1 \text { tespit edilmiştir. }\end{array}$ \\
\hline $\begin{array}{l}\text { Eyden } \\
\text { vd., } \\
(2019)\end{array}$ & $\begin{array}{c}17 \text { OECD } \\
\text { Ülkesi } \\
(1870-2013)\end{array}$ & $\begin{array}{c}\text { Genel } \\
\text { Değerlendirme }\end{array}$ & $\begin{array}{l}\text { Petrol fiyatlarındaki oynaklık ile reel } \\
\text { ekonomik büyüme arasında negatif } \\
\text { ve anlamlı bir ilişki bulunmuştur. }\end{array}$ \\
\hline $\begin{array}{l}\text { Anik } \\
\& \\
\text { Biplob } \\
(2019)\end{array}$ & $\begin{array}{l}\text { Bangladeş } \\
(1987-2017)\end{array}$ & $\begin{array}{l}\text { VECM } \\
\text { Analizi }\end{array}$ & $\begin{array}{l}\text { Reel döviz kuru, ticari açıllk, faiz } \\
\text { oranı ve para arzının ekonomik } \\
\text { büyüme ile uzun dönemli ilişki } \\
\text { içerisinde olduğu sonucuna } \\
\text { ulaşılmıştır. Aynı zamanda ticari } \\
\text { açıklık ve para arzından büyümeye }\end{array}$ \\
\hline
\end{tabular}


Kazanc1, B. A.; Tümer, T.; Ülker, H. Ö. \& Aytekin, İ. (2021), “İktisadi Büyüme Teorilerini Yeniden Düşünmek: Avustralya ve Bangladeş Örneği”, Politik Ekonomik Kuram, 5 (1), 19-33.

\begin{tabular}{|c|c|c|c|}
\hline & & & $\begin{array}{l}\text { doğru nedensellik ilişkisi tespit } \\
\text { edilmiştir. }\end{array}$ \\
\hline $\begin{array}{c}\text { Xue } \\
(2020)\end{array}$ & $\begin{array}{c}50 \text { Ülke } \\
(1997-2014)\end{array}$ & $\begin{array}{l}\text { Dinamik Panel } \\
\text { Veri Analizi }\end{array}$ & $\begin{array}{l}\text { Gelişmiş ülkelerde söz konusu } \\
\text { oynaklığı gelişmekte olan ülkelere } \\
\text { göre daha az olduğunu tespit } \\
\text { edilmiştir. İncelenen ülkeler arasında } \\
\text { Bangladeş'in kamu büyüklüğü } \\
\text { açısından en küçük (0,05), } \\
\text { (ihracat+ithalat)/GDP ile ölçülen } \\
\text { ticari dişa açılık oranı açısından ise } \\
\text { en kapalı }(0,36) \text { üçüncü ülke olması } \\
\text { dikkat çeken sonuçlardan biridir. }\end{array}$ \\
\hline $\begin{array}{c}\mathrm{Vu} \\
\& \\
\text { Hoa } \\
(2020)\end{array}$ & $\begin{array}{c}\text { Avustralya } \\
(-)\end{array}$ & $\begin{array}{l}\text { İstatistiki } \\
\text { Analiz }\end{array}$ & $\begin{array}{l}\text { Çin ve Hindistan'dan Avustralya'ya } \\
\text { yönelik turizmin, ülkenin büyümesi } \\
\text { için kritik bir kaynak olarak } \\
\text { görülmesine rağmen, küçük ve } \\
\text { asimetrik bir etkisi olduğu yönünde } \\
\text { bulgulara ulaş1lmıştır. }\end{array}$ \\
\hline $\begin{array}{l}\text { Aydin } \\
(2020)\end{array}$ & $\begin{array}{c}10 \text { Ülke } \\
(1995-2018)\end{array}$ & $\begin{array}{c}\text { Panel } \\
\text { Nedensellik } \\
\text { Yöntemi }\end{array}$ & $\begin{array}{l}\text { Avustralya'nın yanı sıra ABD, } \\
\text { Fransa, Birleşik Krallık, İtalya ve } \\
\text { Japonya gibi gelişmiş ülkeler için de } \\
\text { turizm ile ekonomik büyümenin } \\
\text { birbirini anlamlı bir şekilde } \\
\text { etkilemediğini ifade eden yansılık } \\
\text { hipotezinin geçerli olduğu sonucuna } \\
\text { ulaşmıștır. }\end{array}$ \\
\hline
\end{tabular}

\section{2. İktisadi Büyüme Teorileri}

Büyüme teorilerinin tarihsel geçmişi oldukça eskiye dayanmaktadır. Ekonomik büyüme klasik ekolün öncesine kadar inmekte olup 17. yüzyılda merkantilizm akımıyla bağ kurulmuştur. Merkantilistlere göre büyümenin kaynağının ülkelerin sahip olduğu değerli madenlerle ihracata bağlı olduğu, Fizyokratlar ise 17. yüzyılın ikinci yarısında Merkantilist görüşe karşı çıkarak, büyümenin kaynağının tarım sektörü olduğu hakkında görüşler hâkim olmuştur. 1770’lü yıllarda ortaya çıan ve klasik büyüme yaklaşımını savunan düşünürlerden Adam Smith büyümenin kaynağını uzmanlaşmadaki ve tasarruflardaki artış olarak belirtmiştir. Ona göre doğal şartlarda büyümekte olan her toplum, sermayesinin önemli bir kısmını öncelikle tarıma, sonra imalata ve daha sonra da dış ticarete yönlendirmektedir (Smith, 1991: 324). David Ricardo ise 1857 yılında yaptığı çalışmalarda büyümenin kaynağını, artık değerin yatırıma dönüşmesi şeklinde vurgulamıştır. Dolayısıyla doğal kaynaklarda azalan verimler yasası, ücretlerin geçim seviyesine düşmesine ve ekonomide durgunluk yaşanmasına ve büyümenin sınırlı kalmasına neden olduğu anlatılmıştır (Pilling, 1972). Thomas R. Malthus 1799 yılında ise, nüfus kanunu nedeniyle sınırlı büyümenin gerçekleştiği savını ortaya atmıştır (Thomlinson, 1976).

Neoklasik büyüme teorisyenleri de Klasikler gibi büyümenin doğada kendiliğinden ortaya çıan bir olgu olduğunu ve aralarında fark olmadığını ileri sürmüştür. Ekonomide dengeden sapma olduğunda sermaye-hasıla oranı uzun dönemde dengeyi yeniden sağlayabildiğini ancak yeterli uzun süre olmadığında ekonomide denge sağlanamadığını iddia etmişlerdir. Yani Neoklasik 
Kazanc1, B. A.; Tümer, T.; Ülker, H. Ö. \& Aytekin, İ. (2021), “İktisadi Büyüme Teorilerini Yeniden Düşünmek: Avustralya ve Bangladeş Örneği”, Politik Ekonomik Kuram, 5 (1), 19-33.

büyüme modeli, uzun dönemli bir model olmakla beraber Harrod Domar modelinin üzerine verimlilik artışının eklenmesiyle yeni bir yaklaşım meydana getirmiştir (Sato, 1964: 387). Solow'un modeli esasında Harrod-Domar modeli bulunmakta olup ancak uzun dönemli büyüme modelini kabul etmiştir. Harrod-Domar modelindeki dengeyi bıçak sırtı dengesi olarak tanımlayarak işgücü-sermaye oranının sabit olduğunu varsaymaktadır (Solow, 1956: 66). Klasik ve Neoklasik büyüme teorileri zaman ilerledikçe yeni teorilere kapı aralamış, 20. yüzyılda yaşanan ekonomik bunalım ve savaş ortamları yeni modern büyüme teorilerinin temellerini atmıştır.

Modern büyüme teorileri, Büyük Buhran ve ikinci dünya savaşında ortaya çıkan gelir farklılıkları neticesinde ortaya çıkmıştır. 1940'l yıllarda Keynesyen ekole mensup Harrod ve Domar tarafindan yapılan çalışmalarla Harrod-Domar modeli ortaya çıkmıştır (Van Den Berg, 2001:110). Bu model, büyümenin motoru olarak doğal kaynaklar yerine sermaye birikimini ileri sürmektedir. Ayrıca uzun dönemli problemleri, kısa dönemli araçlarla çözmeye çalıştığından gelişmiş ülkelerin büyüme deneyimlerini açıklamakta yetersiz kalmaktadır (Solow, 1956: 66).

İçsel büyüme modelleri dış ticaret ve yabancı yatırımların faydaları üzerinde durmuştur. Uzun dönem büyümenin motoru olarak teknolojideki yayılıma yoğunlaşmış ve dişa açık ülkelerin yüksek durağan durum büyüme oranına sahip olacağını iddia etmiştir. Ayrıca azalan verimler yasasını kabul etmemişlerdir (Barro ve Martin, 2004:19-20). İçsel büyüme teorisyenlerinden Romer büyümenin asıl kaynağı olarak Ar-Ge harcamalarının ürünü olan teknolojik gelişmeyi görmektedir (Romer, 1986:1003). Schumpeter'in "yaratıc1 yıkım" kavramı ekonomik büyümenin önemli özelliğini ifade etmektedir. İçsel büyüme modellerinden AK modelinde, sermayenin azalan marjinal getirisi yok sayılarak teknolojik gelişme olmadığı durumlarda bile uzun dönemde kişi başı büyümenin sürdürülebileceği bu model Rebelo tarafından ortaya konmaktadır (Rebelo, 1991:509). Barro'nun çalışmasında ise ölçeğe göre sabit getiri içeren üretim fonksiyonunda kamu kesiminin dikkate alınmasıyla ülkelerin başlangıçtaki büyüme seviyelerine ve beşeri sermaye birikimlerine bağlı olmaktadır (Barro,1991:437). Lucas (1988)'ın çalışmasında ise uzun dönem büyüme sürecinde beşeri sermayeye fiziksel sermayeden daha çok önem verilmektedir (Lucas, 1988:20).

\section{Avustralya ve Bangladeş'in Makro İktisadi Yapıları}

Avustralya ve Bangladeş son otuz yılda iktisadi büyüme açısından dünya'da istikrarı yakalamış iki ülkedir. Bu ülkelerde konjonktürel dalgalanmaların çok az derecede yaşanmış olması, küresel çapta bu ülkeleri diğer gelişmiş, gelişmekte olan ve az gelişmiş ülkelere göre ayrıcalıklı kılmaktadır. Literatürde iktisadi açıdan yeteri kadar ele alınmayan bu iki ülkeye yönelik olarak yapılan bu çalışma bu bakımdan önem arz etmektedir. Genel bir iktisadi kompozisyon bu bağlamda değer atfetmektedir.

\subsection{Avustralya'nın Makro İktisadi Yapısı}

1980'lerden günümüze kadar Avustralya ekonomisinde ciddi reformlar yapılmış, bu tarihten itibaren Avustralya korumacı ve kapalı piyasa sisteminden ihracata dayalı ve rekabetçi bir sanayi yapısına geçiş yapmıştır. Bu düzenlemeler ve gelişmeler; gümrük vergilerinin azaltılması, dalgalı kura geçiş, finans sektöründe kısıtlamaların kaldırılması, vergi sistemindeki reformlar ve kamu işletmelerinin özelleştirmesi şeklinde sayılabilir. Bu gelişmeler ekonomiyi şaha kaldırmış ve son 20 yıldan bu yana düzenli büyüme, kontrol altına alınmış enflasyon, düşük kamu borcu ve güçlenmiş finans sistemi olarak görülmektedir. Sektörel dağılıma bakıldığında ekonominin büyük kısmı hizmet sektörünün elindedir. Buna ek olarak madencilik ve tarım sektörlerinin ihracatta önemli bir yeri vardır (Ticaret Bakanlığı, 2020: 5-6). 
Avustralya dış ticaretinde ihracat gelirlerinin \%61'lik kısmı fuel ve mineral ürünler, \%18'lik kısmı ise tarım ürünlerinden elde edilmektedir. İhracatta en önemli ortak \%34 ile Çin olurken Çin'i \%16’lık payla Japonya takip etmektedir. İthalatta ise bağımlı olunan ilk ülke \%24 oranla Çin olurken, Çin'i \%18'lik payla Avrupa Birliği takip etmektedir (WTO, 2019: 22). Rakamlardan da anlaşıldığı üzere Avustralya'nın ihracatında yeraltı kaynaklarının büyük bir payı vardır. Bu zenginliğin yanı sıra, tarım ürünlerinin ihracat gelirlerinde ikinci sırada yer alması, Avustralya'nın topraklarını verimli bir şekilde kullandığı sonucu ortaya çıkmaktadır. Tablo 2'de Avustralya'nın son üç yıldaki ortalama temel makro iktisadi göstergeleri verilmiştir.

Tablo 2. Avustralya'nın 2017-2019 Yılları Arasında Temel Makro Ekonomik Göstergeleri

\begin{tabular}{|c|c|}
\hline Göstergeler & $\mathbf{2 0 1 7 - 2 0 1 9}$ \\
\hline GSYH (Ortalama Milyar Dolar) & 1386 \\
\hline Kişi Başına Düşen Gelir (Bin Dolar) & 55.480 \\
\hline Cari Hesap Dengesi (\%) & -1.24 \\
\hline Enflasyon Oranı (\%) & 1.82 \\
\hline
\end{tabular}

Kaynak: https://data.worldbank.org/?locations=BD-AU, (Erişim Tarihi: 12.12.2020)

Tablo 2'de görüldüğü üzere Avustralya'nın son üç yılda elde ettiği ortalama GSYİH 1 trilyon 386 milyar dolara ulaşmış ve dünyanın en büyük 13. ekonomisi konumunda yer almıştır. Son üç yılda ortalama kişi başına düşen milli gelirde ise dünya ülkelerine kıyasla ikinci sıraya yerleşmiş ve bu rakam 55.480 dolar olmuştur. Avustralya'nın Tablo 2'de yer alan bir diğer göstergesi olan yıllık enflasyon rakamları incelendiğinde de Avustralya'da enflasyon istikrarının yakalandığ anlaşılmaktadır. Son olarak Tablo 2'de yer alan cari hesap dengesi ise \%1, 24 oranında açık vermiş̧ir. Bu cari açığın temel nedeni, ihracatın yarıdan fazlasını karşılayan fosil yakıtların küresel çaptaki fiyat düşüşlerinden kaynaklanabilir.

\subsection{Bangladeş'in Makro İktisadi Yapısı}

1980'lerde IMF ve Dünya Bankası tarafından politika reformlarının hayata geçirilmesiyle Bangladeş ekonomisinde önemli gelişmeler kaydedilmiştir. Azalan dış yardımlar ve ticaret hadlerinin bozulması ve makroekonomik dengesizliklerin artışı bu reformların temel nedenlerindendir. $\mathrm{Bu}$ yılda yapılan başlıca reformlar ise; kamunun piyasa etkisinin azaltılması, tarım ve gıda da sübvansiyonları kısma, finansal serbestiyi sağlama, ithalat kısıtlamalarının kaldırılması ile gerçekleşmiştir. Bu politika sonucunda siyasi istikrarın sağlanması ile birlikte 1990'larda doğrudan yabanc1 yatırımlarda artışlar meydana gelmiştir (Hossain, 2017: 35-36).

2017 yılı ürün gruplarına göre incelenen rakamlarda Bangladeş ihracatının neredeyse tamamına yakını (\%93) imalat sektörünün elindedir. Tarımın ihracattaki payı ise \%3’tür. İthalatta ise \%58 imalat, tarımda ise $\% 30$ oranında dışa bağımlıdır. Ülkeler bazında Bangladeş AB ülkelerine \%53, ABD'ye ise \%19 oranın ihracat yapmıştır. İthalatta pasta payının en büyügü sırayla Çin, Hindistan ve Singapur'dadır. Tablo 3'te Bangladeş'in son üç yıldaki ortalama temel makro iktisadi göstergeleri verilmiştir. 
Tablo 3. Bangladeş'in 2017-2019 Yılları Arasındaki Temel Makro Ekonomik Göstergeleri

\begin{tabular}{|c|c|}
\hline Göstergeler & $\mathbf{2 0 1 7 - 2 0 1 9}$ \\
\hline GSYH (Ortalama Milyar Dolar) & 275.4 \\
\hline Kişi Başına Düşen Gelir (Bin Dolar) & 1.705 \\
\hline Cari Hesap Dengesi & -2.4 \\
\hline Enflasyon Oranı (\%) & 5.612 \\
\hline
\end{tabular}

Kaynak: https://data.worldbank.org/?locations=BD-AU, (Erişim Tarihi: 12.12.2020)

Tablo 3'te verilen 3 y1llık ortalamalara göre Bangladeş'in GSYH'si 275 milyar dolardır. Bu GSYIH dünya sıralamasına göre oldukça düşük ve Bangladeş’i Dünya GSYïH sıralamasında 41. sıraya yerleştirmektedir. Kişi başına düşen milli gelirde de Bangladeş 1.705 dolar ile düşük gelirli ülkeler konumunda yer almaktadır. Enflasyon oranın düşük seyretmesi, atalet kazanacak düzleme çımaması ekonomik denge açısından önem arz etmektedir. Cari açık problemi Bangladeş özelinde de görülmektedir. $\mathrm{Bu}$ durum mevcut ülkenin temel ürünlerde dişa bağımlı olmasından kaynaklanma ihtimalinin yüksek olduğu kanısını doğrular niteliktedir.

Dış ticarete bağımlı bir ekonomiye dönüşen Bangladeş’te yatırıma yönelik atılım henüz gerçekleştirilememiştir. Hazır giyim sektörünün yanında emek yoğun iş gücü ekonominin temel dinamikleridir. Düşük ücretli iş gücü potansiyelini Bangladeş ekonomik alanlarda iyi kullanmaktadır (Ticaret Bakanlığı, 2020: 5).

\section{Küresel Ekonomik Büyüme Verilerinin Analizi}

Avustralya ve Bangladeş küresel ekonomik büyüme rakamlarına göre gözle görülür biçimde ekonomik büyüme istikrarı sağlayan iki ülke olmuştur. Bilakis bu makalenin çekirdeğinde mevcut iki ülkenin küresel çapta analizi stratejik ehemmiyeti vardır. Bu eksende 196 ülkenin iktisadi büyüme rakamları incelenmiş ve analizde yıllık rakamlar kullanılmıştır. Analizde kullanılan veriler Dünya Bankası (WB) ve Uluslararası Para Fonu (IMF) veri tabanlarından temin edilmiştir. Çalışmada dönem olarak 1990-2019 yılları arasını kapsayan 30 yıllık bir zaman serisi kullanılmıştır. Hesaplamalarda Excel programı kullanılmıştır.

Bu çalışmada 196 ülkenin iktisadi büyüme rakamları tek tek incelenmiş ve incelenen bu rakamlar Dünya'nın iktisadi büyüme rakamlarıyla karşıllaştııılmıştır. Yapılan bu karşılaş̧ırmalar neticesinde Dünya'da iki ülkenin iktisadi büyüme rakamlarının sürekli Dünya iktisadi büyüme rakamlarına paralel veya üzerinde seyrettiği ve bu iki ülkenin küresel krizler ile şoklardan az etkilendikleri görülmüştür. Bu iki ülke Bangladeş ve Avustralya'dır. Bu ülkelerin büyüme rakamları ile Dünya'nın iktisadi büyüme rakamlarının karşılaştırıldığı zaman yolu grafiği aşağıda Şekil 1'de verilmiştir. 
Şekil 1: Bangladeş, Avustralya ve Dünya'nın Büyüme Rakamlarının 1990-2019 Yılları Arasındaki Zaman Yolu Grafiği

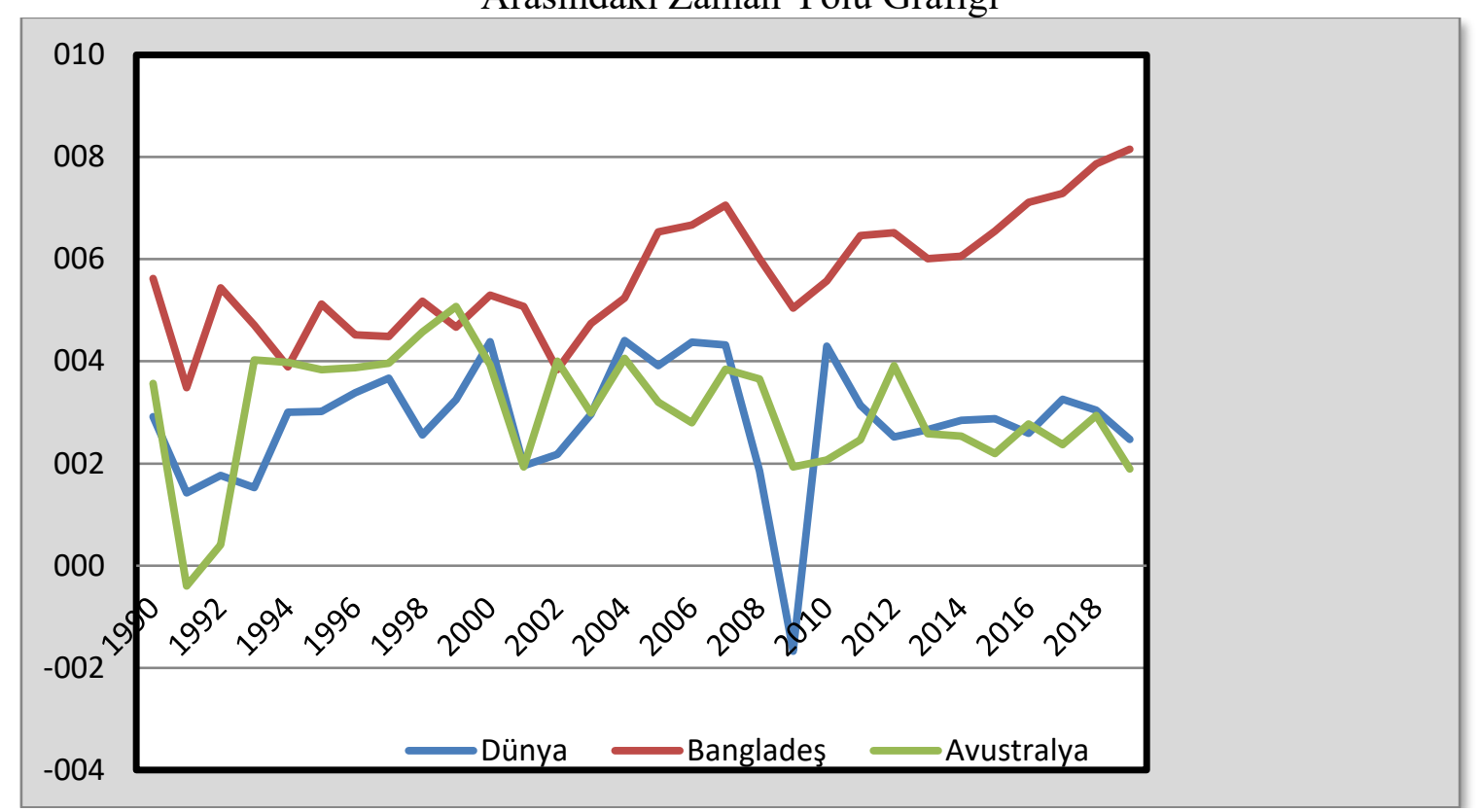

Kaynak: https://data.worldbank.org, 2020. (Grafik yazarlar tarafindan oluşturulmuştur).

Şekil 1'de görüldüğü üzere Dünya'nın iktisadi büyüme rakamları \%2 ile \%4 bandı aralığında dalgalanarak istikrarlı bir trend yakalamıştır. Ancak 2008 küresel finansal krizi Dünya'nın iktisadi olarak büyümesine olumsuz bir şekilde yansımış ve şekilde de görüldüğü üzere bu dönemde Dünya ekonomisinde yaklaşık olarak \%2'lik bir daralma görülmüştür. Ancak bu olumsuz etki kısa sürmüş ve Dünya ekonomisi V şeklinde bir toparlanmayla eski haline dönmüştür. Şekil 1'de yer alan ve bir diğer konu olan Bangladeş ekonomisi, 1990'dan 2002 yılına kadar \%4 ile \%6 bandı aralığından dalgalanan bir büyüme trendi yakalarken, 2002'den günümüze kadar ise sürekli artış gösteren bir iktisadi büyüme trendi yakalamıştır. Bangladeş' in 30 yıllık süreçte büyüme rakamları hiçbir zaman Dünya ortalamasının altına inmemiş ve 2019 yılında Bangladeş \%8'in üzerinde bir büyüme performansı sergilemiş̦tir. Şekil 1'de yer alan bir diğer ülke olan Avustralya ise Bangladeş'e göre daha düşük bir iktisadi büyüme performansı sergilemesine karşın, Dünya'nın iktisadi büyüme rakamlarına yakın veya üzerinde bir performans sergilemiştir. Şekil 1'den da anlaşıldığı üzere Avustralya'nın büyüme rakamları istikrarlı ve durağan bir trend sergilemektedir. Son olarak bu iki ülkenin küresel finansal krizden az etkilendikleri anlaşılmaktadır. Bundan sonraki aşamada Şekil 1'de verilen rakamların istatistiki hesaplamaları yapılarak Tablo 4'te verilmiştir.

Tablo 4; Dünyanın, Avustralya ve Bangladeş'in 30 yıllık büyüme rakamlarına yönelik ortalama, standart sapma ve korelasyon katsayılarını göstermektedir. Dünya'daki 196 ülke üzerine yapılan bu hesaplamalarda Dünya ortalama büyüme rakamlarına göre Bangladeş ve Avustralya için ilginç sonuçlara ulaşılmıştır. 
Tablo 4: Avustralya ve Bangladeş'in Büyüme Rakamlarına İlişkin İstatistiki Bilgiler

\begin{tabular}{|c|c|c|c|c|}
\hline Ülkeler & $\begin{array}{c}\text { Ortalama } \\
\text { Büyüme }\end{array}$ & $\begin{array}{c}\text { Büyümenin } \\
\text { Standart Sapması }\end{array}$ & $\begin{array}{c}\text { Büyümenin } \\
\text { Varyansı }\end{array}$ & $\begin{array}{c}\text { Büyümenin } \\
\text { Korelasyon Katsayısı }\end{array}$ \\
\hline Dünya & 2,83 & 1,20 & 1.45 & 1 \\
\hline Avustralya & 3.03 & 1.19 & 1.41 & +0.37 \\
\hline Bangladeș & 5.67 & 1.18 & 1.39 & +0.23 \\
\hline
\end{tabular}

Kaynak: https://data.worldbank.org, ve https://www.imf.org/en/Publications/WEO,

(Hesaplamalar yazarlar tarafindan yapılmıştır)

Tablo 4'te verilen dünya ile Avustralya'nın iktisadi büyüme performansları karşılaştırıldığında, Avustralya'nın 30 yıllık ortalama iktisadi büyüme performansının dünya iktisadi büyüme ortalamasının üzerinde seyrettiğini, ancak iktisadi büyümenin standart sapması ile varyansının ise dünyanın iktisadi büyüme standart sapması ile varyansından küçük olduğu görülmektedir. $\mathrm{Bu}$ sonuca göre Avustralya'nın 30 yıllık süreçte iktisadi büyümede istikrarı yakaladığı söylenebilir. Ayrıca Avustralya ile dünyanın iktisadi büyüme rakamları arasında 0,37'lik bir değerle zayıf ve pozitif yönlü bir korelasyonun (ilişkinin) olduğu tabloda görülmektedir.

Aynı tabloda yer alan bir diğer ülke Bangladeş ile dünyanın iktisadi büyüme performansları karşılaştırıldığında ise Bangladeş'in de 30 yıllık iktisadi büyüme performansının Dünya'nın iktisadi büyüme ortalamasının üzerinde seyrettiğini, ancak iktisadi büyümenin standart sapması ile varyansının ise Dünya'nın iktisadi büyüme standart sapması ile varyansından küçük olduğu görülmektedir. Bu sonuç Bangladeş'in de 30 yıllık süreçte iktisadi büyümede istikrarı yakaladığı anlamına gelmektedir. Ayrıca Bangladeş ile Dünya'nın iktisadi büyüme rakamları arasında 0,23’lük bir değerle zayıf ve pozitif yönlü bir korelasyonun (ilişkinin) olduğu tabloda görülmektedir.

Tablo 4'ten de anlaşıldığı üzere yapılan analizde Avustralya ve Bangladeş' in 30 yıllık ortalama büyüme performanslarının dünyanın ortalama büyüme performansından daha iyi konumda olduğu sonucuna varılmıştır. Avustralya iktisadi olarak gelişmiş ülkeler kategorisinde yer alırken, Bangladeş'in ise gelişmekte olan Asya ülkeleri kategorisinde yer almasına karşın iki ülkenin 30 yıllık süreçte gösterdiği iktisadi büyüme başarısı benzerdir. Özellikle de bu iki ülkenin farklı iktisadi ve toplumsal yapılara sahip olmalarına rağmen iktisadi büyümede benzer başarıları göstermeleri iktisadi büyüme teorilerinin yeniden gözden geçirilmesini zorunlu hale getirmiştir.

Tablo 5'te Dünya ekonomisinde Avustralya ve Bangladeş ile karşılaştırılmak üzere bu iki ülkenin iktisadi büyüme performansına yakın ve uzak performans sergileyen 6 ülke seçilmiştir. Bu ülkeler Arjantin, Brezilya, Vietnam, Türkiye, Yeni Zelanda ve Portekiz ülkelerinden oluşmaktadır. 
Kazanc1, B. A.; Tümer, T.; Ülker, H. Ö. \& Aytekin, İ. (2021), “İktisadi Büyüme Teorilerini Yeniden Düşünmek: Avustralya ve Bangladeş Örneği”, Politik Ekonomik Kuram, 5 (1), 19-33.

Tablo 5: Seçilmiş Ülkeler ile Avustralya ve Bangladeş'in Büyüme Rakamlarının

Karşılaştırılması

\begin{tabular}{|c|c|c|c|c|}
\hline Ülkeler & $\begin{array}{c}\text { Ortalama } \\
\text { Büyüme }\end{array}$ & $\begin{array}{c}\text { Büyümenin } \\
\text { Standart Sapması }\end{array}$ & $\begin{array}{c}\text { Büyümenin } \\
\text { Varyansı }\end{array}$ & $\begin{array}{c}\text { Büyümenin } \\
\text { Korelasyon Katsayısı }\end{array}$ \\
\hline Dünya & 2,83 & 1,20 & 1.45 & 1 \\
\hline Avustralya & 3.03 & 1.19 & 1.41 & +0.37 \\
\hline Bangladeș & 5.67 & 1.18 & 1.39 & +0.23 \\
\hline Arjantin & 2,63 & 5,66 & 32,07 & $+0,39$ \\
\hline Brezilya & 2,22 & 2,74 & 7,52 & $+0,39$ \\
\hline Vietnam & 6,79 & 1,24 & 1,54 & $+0,26$ \\
\hline Türkiye & 4,60 & 4,56 & 20,80 & $+0,54$ \\
\hline Yeni Zellanda & 2,83 & 1,83 & 3,35 & $+0,34$ \\
\hline Portekiz & 1,56 & 2,31 & 5,31 & $+0,43$ \\
\hline
\end{tabular}

Kaynak: https://data.worldbank.org, ve https://www.imf.org/en/Publications/WEO,

(Hesaplamalar yazarlar tarafindan yapılmıştır)

Türkiye'nin yukarıdaki Tablo 5 'te yer alan ortalama büyüme rakamı incelendiğinde, Türkiye'nin 30 yıllık büyüme ortalamasının 4.60 olduğu ve bu ortalamanın dünya büyüme ortalamasının yaklaşık olarak 2 katından fazla olduğu görülmektedir. Türkiye'nin büyüme rakamlarının standart sapmasına baktığımızda ise 4,56 olarak hesaplanmıştır. Bu standart sapmanın ortalamaya yakın bir voltalite olduğu da anlaşılmaktadır. Bu rakam ise dünya büyüme rakamlarının standart sapmasının nerdeyse 4 katına denk gelmektedir. Bu durum Türkiye'nin 30 yıllık süreçte iktisadi büyümede istikrarlı bir trendi yakalayamadığını ve yıllar itibariyle büyümede ciddi dalgalanmaların olduğu anlamına gelmektedir. Ayrıca Türkiye'nin ve dünyanın büyüme rakamları arasında 0,54'lük bir değerle orta düzey ve pozitif yönlü bir korelasyonun (ilişkinin) olduğu tespit edilmiştir. Yani Türkiye'nin 30 yıllık süreçte ortalama büyüme hareketleri dünya'nın ortalama büyüme hareketleri ile benzer yönde hareket etmektedir. Bu durum ise küresel çapta yaşanacak olumsuz bir iktisadi gelişme veya şokların Türkiye'nin makro iktisadi yapısının kırılgan hale gelmesine zemin hazırlamaktadır.

Türkiye'nin büyüme varyansına benzerlik gösteren tek ülke ise Arjantin'dir. Arjantin'in ortalama büyüme rakamı Dünya ortalamasının altında olmasının yanı sıra, ortalama büyüme varyansı ve standart sapması Türkiye'den bile yüksektir. Bu durum Arjantin'de de 30 yıllık süre zarfinda büyümede istikrarlı bir trendin yakalanmadığı anlamına gelmektedir. Ayrıca Arjantin'in ve Dünya'nın büyüme rakamları arasında korelasyon katsayısı 0,39'luk bir değerle, Türkiye'ye nazaran daha zayıf ve pozitif yönlüdür. Bu bağlamda Türkiye ile Arjantin'i Avustralya ve Bangladeş ile karşıllaştırdığımızda her iki ülkenin de 30 yıllık süreçte iktisadi büyümede istikrarı yakalayamadıklarını ve iktisadi büyümede ciddi dalgalanmaların yaşandığı sonucuna ulaşılmışıtır. Tablo 5'te yer alan diğer ülkeler ise Brezilya, Vietnam, Yeni Zelanda ve Portekiz'dir. Bu ülkelerden Vietnam'ın ortalama büyüme rakamı Dünya ortalamasının üzerindeyken, Portekiz ile Brezilya'nın ortalama büyüme rakamları Dünya ortalamasının altında, Yeni Zelanda'nın ise Dünya ortalamasına eşit olduğu görülmektedir. Fakat bu ülkelerin büyüme rakamlarının standart sapmaları ile varyanslarının ise düşük ve Dünya'nın iktisadi büyüme rakamlarının varyans ve standart sapmasına yakın olduğu görülmektedir. Ayrıca bu ülkelerden Brezilya, Vietnam ve Yeni Zelanda'nın iktisadi büyüme rakamları ile Dünya'nın iktisadi büyüme rakamları arasında zayıf ve pozitif yönlü bir korelasyonun (ilişkinin) olduğu, fakat Portekiz'in iktisadi büyüme rakamları ile Dünya'nın iktisadi büyüme rakamları arasında 0,43 'lük bir değerle orta düzey ve pozitif yönlü bir 
Kazanc1, B. A.; Tümer, T.; Ülker, H. Ö. \& Aytekin, İ. (2021), “İktisadi Büyüme Teorilerini Yeniden Düşünmek: Avustralya ve Bangladeş Örneği”, Politik Ekonomik Kuram, 5 (1), 19-33.

korelasyonun (ilişkinin) olduğu tespit edilmiştir. Sonuç olarak bu ülkelerde iktisadi büyümede istikrarın yakalanması adına ciddi bir mesafe kat edildiği ve biraz daha çabayla büyümenin Avustralya ve Bangladeş'e benzer bir istikrara kavuşacağı söylenebilir. Ayrıca ülkelerin korelasyon katsayıları düşük ve pozitif yönlüdür.

\section{Sonuç ve Değerlendirme}

Avustralya ekonomisi dünyanın ilk 13 ekonomisi arasında yer alması ve yüksek kişi başına düşen gelire sahip olmasına rağmen yaşanan küresel ve ekonomik krizlere dayanıklı ekonomik dirence sahip olduğu makro ekonomik performanstan anlaşılmaktadır. Ancak dışarıya satılan fosil yakıtların dünya fiyatlarının artış veya azalışı cari açık olgusuna etki ettiği verilerden gözlemlenmiştir. Haricindeki enflasyonun istikrarlı oluşu, kişi başına düşen gelirde dünyada sayılı ülkelerden biri olması temel verilerden yola çıkarak ekonomik istikrarın iki alana da yayıldığı söylenebilir.

Bangladeş'te yakalanan ekonomik büyümedeki istikrar ön plana çıksa da makro verilerde Avustralya'nın bir hayli gerisinde olduğunu gözler önüne serilmiştir. Kişi başına düşen gelirdeki düşüklük, cari açıtaki dengesizlik problemi gibi etmenler ekonomik büyümedeki istikrarın yansımalarını vermemektedir. Buradan çıkarılacak sonuçlardan bir tanesi de ekonomik büyümede gerekli istikrar yakalansa da bunun domino etkisi meydana getirmeyeceği aşikardır. Bu durumda yapısal iktisadi problemlerle baş başa kalındığı eleştirisini yapmak gerekmektedir.

Bangladeş ve Avustralya'nın korelasyon katsayılarının zayıf ve pozitif yönlü olması bu ülkelerin ekonomilerinin dişsal şoklara karşı daha dirençli oldukları anlamına gelmektedir. Nitekim bu iki ülke 2008 yllında yaşanan Küresel Finansal Krizden en az etkilenmeleri ekonomilerindeki bu direnci ispatlar niteliktedir. Ayrıca bu ülkelerdeki enflasyon ve işsizlik rakamlarının tek hanelerde ve düşük olması ekonomilerinde hedeflenen politikalara ulaşıldığını teyit etmektedir.

Özellikle büyüme teorileri oluşturulurken teorilerde yer verilen iki ülke varsayımlarında her iki ülkenin eşit şartlarda, benzer üretim faktörleri ve teknolojik gelişmelerle üretim yaptıkları kabul edilir. Fakat yapılan bu çalışmada Avustralya ve Bangladeş'in tamamen farklı iktisadi yapı ve özelliklere sahip olmalarına karşın 30 yıllık süreçte aynı büyüme performansı sergiledikleri görülmüştür. $\mathrm{Bu}$ durum literatürdeki büyüme modellerinin yeniden oluşan küresel düzen ile entegrasyon bölgelerine göre kategorize edilip güncellenmesi gerektiği sonucunu doğurmuştur. $\mathrm{Bu}$ bütünleşme hareketleri ticaret ekseninde karşılıklı tamamlayıcılık ilişkilerine de kapı aralayacaktır. Sonuç olarak yapılan bu çalışmada, biri gelişmiş biri gelişmekte olan ve iktisadi olarak farklı yapı ve teknolojilere sahip olmalarına karşın iktisadi büyümede benzer performans sergileyen Bangladeş ve Avustralya'nın bu durumunu literatürde izah edecek bir iktisadi büyüme teorisinin olmadığı anlaşılmıştır. Bu nedenle değişen küresel konjonktür koşulları 1şığında günümüzde büyüme teorilerinin yeniden düşünülmesi ve güncellenmesi gerektiği sonucuna ulaşılmıştır. $\mathrm{Bu}$ bağlamda, günümüzde yaşanan teknolojik gelişmeler, üretimde otomasyon ve robot sistemlerin ağırlık kazanması, finansal ve iktisadi küreselleşme, küresel ekonomide yaşanan dijital dönüşüm, ulusal sınırların ortadan kalkması, ticari entegrasyonlar, yapay zekâ, doğrudan yabancı yatırımlar ile çok uluslu şirketlerin ortaya çıkışı gibi durumlar göz önünde bulundurularak iktisadi büyüme teorilerinin yeniden gözden geçirilmesi ihtiyacını doğmuştur.

\section{Kaynakça}

Anik, T.H. ve Biplob, N.K. 2019. Economic Growth and Macroeconomic Fundamentals: Evidence from Bangladesh. Global Journal Of Management And Business Research, . 
from https://www.journalofbusiness.org/index.php/GJMBR/article/view/2697 (Erişim Tarihi, 20/12/2020).

Aydın, M . 2020. En Fazla Turizm Gelirine Sahip 10 Ülke İçin Turizm Gelirleri- Ekonomik Büyüme İlişkisi: Panel Nedensellik Yaklaşımı. Hacettepe Üniversitesi İktisadi ve İdari Bilimler Fakültesi Dergisi, 38 (2) , 215-227 . DOI: 10.17065/huniibf.542850

Banerjee, R. 2012. Population Growth and Endogenous Technological Change: Australian Economic Growth in The Long Run. Economic Record, 88, 214-228. https://doi.org/10.1111/j.1475-932.2011.00784.x

Barro, R. J. 1991. Economic Growth in a Cross Section of Countries. Quarterly Journal of Economics, 106(2), 407 - 443.

Barro, R. J.-i.-M. 2004. Economic Growth. Cambridge: Mass:MIT Press.

Berg, H. V. 2001. Economic Growth and Development. New York: McGraw Hill

Cashin, P., K. Mohaddes, and M. Raissi. 2016. "China's Slowdown and Global Financial Market Volatility: Is World Growth Losing Out?" IMF Working Paper 16/63, International Monetary Fund, Washington. https://doi.org/10.1016/j.ememar.2017.05.001

Eyden, R., Difeto, M., Gupta, R.,Wohar, M.E. 2019. “Oil Price Volatility and Economic Growth: Evidence From Advanced Economies Using More Than a Century's Data Applied Energy, 233-234, pp. 612-621 https://doi.org/10.1016/j.apenergy.2018.10.049

Groenewold, N. 2018. "China's "New Normal”: How will China's Growth Slowdown Affect Australia's Growth?", Australian Economic Papers, 57(4), 435-445.

Hanif, N. ve Arshed, N. 2016. Relationship Between School Education and Economic Growth: SAARC Countries. International Journal of Economics and Financial Issues, 6(1), 294300.

Hoa, T. V. ve Vu, J. 2020. Contribution of Chinese and Indian Tourism to Australia: A Comparative Econometric Study. Archives of Business Research, 8(1), 107-120.

Hossain, A. ve Hossain, M. K. 2012. Empirical Relationship Between Foreign Direct İnvestment And Economic Output in South Asian Countries: A study on Bangladesh, Pakistan and India. International Business Research, 5(1), 9. http://dx.doi.org/10.5539/ibr.v5n1p9

Hossain T. 2017. Bangladeş'in Kalkınmasında Özel Sektörün Rolü, Yayımlanmış Yüksek Lisans Tezi, Ankara: Gazi Üniversitesi

Hussain, M. ve Haque, M. 2016. Foreign Direct Investment, Trade, And Economic Growth: An Empirical Analysis of Bangladesh, Economies, ISSN 2227-7099, MDPI, Basel, Vol. 4, Iss. 2, pp. 1-14, http://dx.doi.org/10.3390/economies4020007 
Islam M S ve Muneer S 2018. Human Development and Economic Growth Nexus: A Comparative Study Between Bangladesh and Pakistan, Pacific Business Review International, Volume 11 Issue 3, September 2018.

Khan, H. ve Bashar, O. 2015. Social Expenditure And Economic Growth: Evidence From Australia And New Zealand Using Cointegration And Causality Tests. The Journal of Developing Areas, 49(4), 285-300. from https://www.jstor.org/stable/24737383, (Erişim Tarihi, $21 / 12 / 2020)$.

Nicolaas G 2018. China's 'New Normal': How Will China's Growth Slowdown Affect Australia's Growth. Australian Economic Paper 57:435-445, https://doi.org/10.1111/14678454.12121

Paramati, S.R., Alam, M.S., Chen, C.F. 2017. The Effects of Tourism on Economic Growth and $\mathrm{CO}_{2}$ Emissions: A Comparison Between Developed and Developing Economies Journal of Travel Research, 56 (6) pp. 712-724, https://doi.org/10.1177/0047287516667848

Pilling, G. 1972. The Law of Value in Ricardo and Marx. Economy and Society, Cilt 1, Say1 3, s.281-307.

Rebello, S. 1991. Long Run Policy Analysis and Long Run Growth. Journal of Political Economy, XCIV(5), 1002-1037.

Romer, P. M. 1986. Increasing Returns and Long-Run Growth. Journal of Political Economy, 94(5), 1002-1037.

Sato, R. 1964. The Harrod Domar Model vs the Neo-Classical Growth Model. The Economic Journal, 74(294), 380 - 387.

Shafiullah, S., Selvanathan, S., Naranpanawa, A. 2017. The Role of Export Composition in ExportLed Growth in Australia and its Regions, Economic Analysis and Policy, Volume 53, Pages 62-76, ISSN 0313-5926, https://doi.org/10.1016/j.eap.2016.11.002.

Smith, A. 1991. Wealth of Nations. Great Minds Series, New York.

Solow, R. M. 1956. A Contribution To The Theory Of Economic Growth. Quarterly Journal Of Economics, $65-94$.

The World Bank (WB), 2020. https://data.worldbank.org/, (Erişim Tarihi, 24/10/2020).

$\begin{array}{lllll}\text { The International } & \text { Monetary } & \text { Fund } & \text { (IMF) }\end{array}$ https://www.imf.org/en/Publications/WEO/Issues/2020/09/30/world-economic-outlookoctober-2020, (Erişim Tarihi, 22/12/2020).

Thomlinson, R. 1976. Population Dynamics: Causes and Consequences of World Demographic Change. New York: Random House.

$\begin{array}{lllll}\text { T.C } & \text { Ticaret } \quad \text { Bakanlı̆̆ } 1020 . & \text { Avustralya Ülke } & \text { Profili, }\end{array}$ https://ticaret.gov.tr/data/5ebeecbe13b876cbbc36550e/AVUSTRALYA\%C3\%9Clke\%20Profili.pdf, (Erişim Tarihi: 28/12/2020). 
Kazanc1, B. A.; Tümer, T.; Ülker, H. Ö. \& Aytekin, İ. (2021), “İktisadi Büyüme Teorilerini Yeniden Düşünmek:

Avustralya ve Bangladeş Örneği”, Politik Ekonomik Kuram, 5 (1), 19-33.

T.C Ticaret $\quad$ Bakanlığı 2020. Bangladeş Ülke Profili, https://ticaret.gov.tr/data/5f1ff69513b87604785508c9/Banglade\%C5\%9F \%C3\%9Clke Profili_072020.pdf, (Erişim Tarihi: 05.01.2021).

World Trade Organization (WTO), 2020. Trade Profiles 2019, https://www.wto.org/english/res_e/booksp_e/trade_profiles19_e.pdf, (Erişim Tarihi: 25.12.2020).

Xue, W. 2020. Financial Sector Development and Growth Volatility: An International Study. International Review of Economics \& Finance, https://doi. org/10.1016/j.iref.2020.06.025. 